\title{
The feature of papers and citation analysis of eleven journals in tropical medicine indexed by Science Citation Index Expanded
}

\section{Yang Hua}

\author{
Library of Second Hospital, China Medical University, Shenyang 110004, People R China
}

To determine the features of papers, authors, and citation of eleven journals in tropical medicine indexed by Science Citation Index Expanded, the database of the Institute for Scientific Information, we analyzed original articles, editorials, reviews, corrections, letters, biographies, and news published in these journals. The results show that these journals covered 107 countries or regions on six continents. The average number of reference was 23.05, with $87.89 \%$ of the references from periodicals. The Price Index was $31.43 \%$ and the self-citing rate was $7.02 \%$. The references in the first 20 journals ranked by the amount of citation accounted for $36.71 \%$ of the total citations. Brazil, United States, India, and England are more advanced in tropical medicine research. The conclusion is that these journals covered most research done in these countries or regions. Most researches were done by cooperation of the researchers, but many of the publications used outdated articles and should include newer information

Key words: citation analysis - medical literature - tropical medicine

The bibliometric analysis is widely used to reveal the features, developmental trend, and information utilization of a journal, which is the collection and analysis of the publications and their references of academic journals (Garfield 1972, 2000, Rousseau 1987). The recent development and topic of general interest of a discipline could be found out by means of the distribution of research topics, authors, and institutes of the author of certain journal about a discipline. We can realize things such as research in tropical medicine, otorhinolaryngology and clinical medicine (Fava 2001, Roy 2002, Schoonbaert 2004). Tropical medicine is a rising and fast-growing subject; which focuses on the research and treatment of diseases related to parasitology, tropical medical microbiology; infectious and non-infectious diseases, clinical diseases of the tropics. With the development of international tropical medicine research activity, there are nearly 50 tropical medicine journals published in different languages in many countries, and hundreds of thousands of articles were published by these journals and other related subject journals. The purpose of this work was to find out the feature of papers, authors, and citation of the journals in tropical medicine. For this purpose, we chose eleven journals in tropical medicine indexed by Science Citation Index Expanded (SCI-E). This database was chosen because it provides access to current and retrospective bibliographic information, author abstracts, and cited references found in approximately 5900 of the world's leading scholarly scientific and technical journals covering more than 150 disciplines. We used bibliometric analysis to analyze the features of papers including original articles, editorials, reviews, corrections, and letters. This research may provide useful information to researchers in tropical medicine on

E-mail:yangh@cmu2h.org

Received 9 May 2005

Accepted 21 October 2005 how to search literature and get their papers publish, and help the editorial staff in tropical medicine to improve the quality of the journals.

\section{MATERIALS AND METHODS}

The journals chosen are Acta Tropica (monthly, published by Elsevier Science BV), American Journal of Tropical Medicine and Hygiene (monthly, published by Amer Soc Trop Med \& Hygiene), Annals of Tropical Medicine and Parasitology ( 8 issues, published by Maney Publishing), Annals of Tropical Paediatrics (quarterly, published by Maney Publishing), International Journal of Leprosy and Other Mycobacterial Diseases (quarterly, published by Int Journal Leprosy), Journal of Tropical Pediatrics (bimonthly, published by Oxford Univ Press), Leprosy Review (quarterly, published by Lepra), Memorias do Instituto Oswaldo Cruz (8 issues, published by Fundação Oswaldo Cruz), Transactions of the Royal Society of Tropical Medicine and Hygiene (monthly, published by Royal Soc Tropical Medine), Tropical Doctor (quarterly, published by Royal Soc Tropical Medine Press Ltd), and Tropical Medicine \& International Health (monthly, published by Blackwell Publishing Ltd), which are indexed by SCI-E because of their outstanding publications. They are published in different countries and stand for the development of different continents. We collected original articles, editorials, reviews, corrections, letters, biographies, and news published in these journals in 2004, but excluded the supplement issues, and analyzed the quantity of papers, average number of authors, number of co-authored papers, countries or regions of the first authors, number of references, average number of references, year of the references published, price index, selfciting rate, and cross-citing rate of these papers. Price index of a periodical is the ratio of the number of references published in the recent five years to the total number of references. It is one of the criteria for evaluating the novelty of a periodical and an important index to reflect the life span of the periodical sample. Self-citing rate re- 
fers to the rate of citing papers that have been published by the same author/journal. In general, the moderate selfciting rate shows the influence and role of a journal in the discipline, but the higher self-citing rate shows the limitation of the information absorption from other sources. Cross citing rate refers to the citing/cited rate each other among the collection of journals. The present study adopts a descriptive research approach by means of bibliometric analysis.

\section{RESULTS}

In 2004, a total of 1454 papers, with 33,517 references, were published in the analyzed journals. The average number of papers per issue published in these journals ranged from 9.33 to 35.00 (Table I). The average number of reference was 23.05. Among these journals, the average number of references per paper and maximal number of references in one paper in American Journal of Tropical Medicine and Hygiene were both the highest (31.59 and 288). Major types of papers in these journals were articles $(83.84 \%)$, followed by letters $(5.02 \%)$, editorial materials $(4.40 \%)$, and reviews $(3.37 \%)$. The other types were corrections, biography, and news, which accounted for only small percent (Table II).

Among the total 1454 papers, 1431 listed the authors' name. The average number of the author per paper was 5.12. The paper coauthored in the eleven journals accounted for $90.29 \%$ (Table III).

In a total of 1454 papers, 1388 papers included the author's address and were from 107 countries or regions on six continents (Table IV). Fifteen of them published more than 24 articles (Table V), which is $65.92 \%$ of all publications. Nine of them published 15-20 articles, nine published 10-14, fifteen published 5-9, and fifty-nine published 1-4 articles.

The largest amount of references in these journals was periodicals $(87.89 \%)$. Items from books and other sources accounted for only a small part (12.11\%) (Table VI).

The average price index of the eleven journals was $31.43 \%$, and the highest price index was $38.59 \%$ which occurred in Tropical Medicine \& International Health. The peak of citation appeared two or three years after the publication in the eleven journals (Table VII).

The self-citing rates of the eleven journals ranged from 2.11 to $19.09 \%$. The average number was $7.02 \%$ (Table VIII).

TABLE I

Quantity of papers and references of the eleven journals in tropical medicine in 2004

\begin{tabular}{|c|c|c|c|c|c|c|c|}
\hline Journal & $\begin{array}{l}\text { Number } \\
\text { of paper } \\
\text { (A) }\end{array}$ & $\begin{array}{l}\text { Number of } \\
\text { reference } \\
\text { (R) }\end{array}$ & $\mathrm{R} / \mathrm{A}$ & $\begin{array}{c}\text { Maximal number } \\
\text { of reference } \\
\text { in one paper }\end{array}$ & $\begin{array}{c}\text { Average } \\
\text { papers } \\
\text { per issue }\end{array}$ & $\begin{array}{c}\text { Average } \\
\text { pages per } \\
\text { paper }\end{array}$ & $\begin{array}{c}2004 \\
\text { Impact } \\
\text { Factor }\end{array}$ \\
\hline Acta Trop & 136 & 3818 & 28.07 & 92 & 11.33 & 7.95 & 1.952 \\
\hline Am J Trop Med Hyg & 300 & 9476 & 31.59 & 288 & 25.00 & 6.20 & 2.013 \\
\hline Ann Trop Med Parasit & 101 & 2298 & 22.75 & 69 & 12.63 & 8.15 & 1.162 \\
\hline Ann Trop Paediatr & 63 & 1127 & 17.89 & 72 & 15.75 & 5.29 & 0.564 \\
\hline Int J Leprosy & 49 & 728 & 14.86 & 45 & 12.25 & 5.33 & 0.426 \\
\hline J Trop Pediatrics & 97 & 1464 & 15.09 & 40 & 16.17 & 4.00 & 0.579 \\
\hline Leprosy Rev & 83 & 919 & 11.07 & 68 & 20.75 & 4.92 & 0.810 \\
\hline Mem Inst Oswaldo Cruz. & 176 & 4688 & 26.64 & 111 & 22.00 & 5.38 & 0.740 \\
\hline Trans $R$ Soc Trop Med Hyg & 112 & 2530 & 22.59 & 54 & 9.33 & 6.58 & 1.746 \\
\hline Trop Doct & 140 & 1328 & 9.49 & 29 & 35.00 & 2.43 & 0.404 \\
\hline Trop Med Int Health & 197 & 5141 & 26.10 & 101 & 16.42 & 7.18 & 1.969 \\
\hline
\end{tabular}

TABLE II

Types of papers of the eleven journals in tropical medicine in 2004

\begin{tabular}{|c|c|c|c|c|c|c|c|}
\hline \multirow[b]{2}{*}{$\underline{\text { Journal }}$} & \multicolumn{7}{|c|}{ Type of the paper } \\
\hline & Article & Review & Letter & $\begin{array}{c}\text { Editorial } \\
\text { material } \\
\end{array}$ & Correction & $\begin{array}{c}\text { Biographical } \\
\text { item }\end{array}$ & $\begin{array}{r}\text { News } \\
\text { item } \\
\end{array}$ \\
\hline Acta Trop & 125 & 5 & 0 & 5 & 1 & 0 & 0 \\
\hline Am J Trop Med Hyg & 279 & 9 & 2 & 5 & 5 & 0 & 0 \\
\hline Ann Trop Med Parasit & 98 & 2 & 0 & 0 & 1 & 0 & 0 \\
\hline Ann Trop Paediatr & 43 & 3 & 14 & 2 & 0 & 1 & 0 \\
\hline Int J Leprosy & 30 & 0 & 8 & 7 & 0 & 4 & 0 \\
\hline J Trop Pediatrics & 75 & 1 & 11 & 9 & 0 & 0 & 1 \\
\hline Leprosy Rev & 34 & 3 & 11 & 8 & 1 & 3 & 23 \\
\hline Mem Inst Oswaldo Cruz & 166 & 8 & 0 & 1 & 1 & 0 & 0 \\
\hline Trans $R$ Soc Trop Med Hyg & 107 & 1 & 1 & 1 & 2 & 0 & 0 \\
\hline Trop Doct & 93 & 10 & 26 & 10 & 1 & 0 & 0 \\
\hline Trop Med Int Health & 169 & 7 & 0 & 16 & 4 & 1 & 0 \\
\hline
\end{tabular}


TABLE III

Number of authors and state of coauthoring of the eleven journals in tropical medicine in 2004

\begin{tabular}{lccccc}
\hline Journal & $\begin{array}{c}\text { Number of } \\
\text { paper }\end{array}$ & $\begin{array}{c}\text { Number of } \\
\text { author }\end{array}$ & $\begin{array}{c}\text { Average number of } \\
\text { author per paper }\end{array}$ & $\begin{array}{c}\text { Number of } \\
\text { paper coauthored }\end{array}$ & $\begin{array}{c}\text { Proportion of paper } \\
\text { coauthored (\%) }\end{array}$ \\
\hline Acta Trop & 136 & 692 & 5.09 & 128 & 94.12 \\
Am J Trop Med Hyg & 300 & 1911 & 6.37 & 283 & 94.33 \\
Ann Trop Med Parasit & 101 & 542 & 5.37 & 98 & 97.03 \\
Ann Trop Paediatr & 63 & 266 & 4.22 & 58 & 92.06 \\
Int J Leprosy & 49 & 195 & 3.98 & 36 & 73.47 \\
J Trop Pediatrics & 97 & 422 & 4.35 & 87 & 89.69 \\
Leprosy Rev & 60 & 176 & 2.93 & 36 & 60.00 \\
Mem Inst Oswaldo Cruz & 176 & 895 & 5.09 & 168 & 95.45 \\
Trans R Soc Trop Med Hyg & 112 & 653 & 5.83 & 105 & 93.75 \\
Trop Doct & 140 & 465 & 3.32 & 110 & 78.57 \\
Trop Med Int Health & 197 & 1113 & 5.65 & 183 & 92.89 \\
\hline
\end{tabular}

TABLE IV

Geographical distribution of the first authors of the eleven journals in tropical medicine in 2004

\begin{tabular}{|c|c|c|c|c|c|c|c|}
\hline \multirow[b]{2}{*}{ Journal } & \multirow{2}{*}{$\begin{array}{l}\text { Number of } \\
\text { paper with the } \\
\text { authors' address }\end{array}$} & \multicolumn{6}{|c|}{ The continent distribution of the first author } \\
\hline & & Africa & Asia & Europe & North America & Oceania & South America \\
\hline Acta Trop & 136 & 28 & 30 & 38 & 15 & 0 & 25 \\
\hline Am J Trop Med Hyg & 295 & 29 & 50 & 65 & 109 & 5 & 37 \\
\hline Ann Trop Med Parasit & 100 & 17 & 33 & 29 & 16 & 0 & 5 \\
\hline Ann Trop Paediatr & 62 & 15 & 15 & 10 & 20 & 1 & 1 \\
\hline Int J Leprosy & 41 & 0 & 26 & 6 & 4 & 0 & 5 \\
\hline J Trop Pediatrics & 91 & 13 & 29 & 10 & 28 & 0 & 11 \\
\hline Leprosy Rev & 52 & 6 & 26 & 14 & 2 & 0 & 4 \\
\hline Mem Inst Oswaldo Cruz & 174 & 0 & 4 & 7 & 18 & 1 & 144 \\
\hline Trans $R$ Soc Trop Med Hyg & 112 & 27 & 29 & 32 & 9 & 0 & 15 \\
\hline Trop Doct & 133 & 58 & 54 & 13 & 5 & 1 & 2 \\
\hline Trop Med Int Health & 192 & 48 & 28 & 88 & 16 & 0 & 12 \\
\hline
\end{tabular}

TABLE V

Top countries or regions in the eleven journals in tropical medicine in 2004

\begin{tabular}{|c|c|c|c|c|c|c|c|c|c|c|c|c|}
\hline \multirow[b]{2}{*}{$\begin{array}{l}\text { Country } \\
\text { or region }\end{array}$} & \multicolumn{12}{|c|}{ The number of paper of authors form different countries or regions in the eleven journals } \\
\hline & $\begin{array}{l}\text { Acta } \\
\text { Trop }\end{array}$ & $\begin{array}{l}\text { Am J } \\
\text { Trop } \\
\text { Med } \\
\text { Hyg }\end{array}$ & $\begin{array}{c}\text { Ann } \\
\text { Trop } \\
\text { Med } \\
\text { Parasit }\end{array}$ & $\begin{array}{c}\text { Ann } \\
\text { Trop } \\
\text { Paediatr }\end{array}$ & $\begin{array}{l}\text { Int J } \\
\text { Lepr }\end{array}$ & $\begin{array}{l}\text { J Trop } \\
\text { Pediat }\end{array}$ & $\begin{array}{c}\text { Leprosy } \\
\text { Rev }\end{array}$ & $\begin{array}{c}\text { Mem } \\
\text { Inst } \\
\text { Oswaldo } \\
\text { Cruz }\end{array}$ & $\begin{array}{c}\text { Trans } \\
R \text { Soc } \\
\text { Trop } \\
\text { Med Hyg }\end{array}$ & $\begin{array}{l}\text { Trop } \\
\text { Doct }\end{array}$ & $\begin{array}{c}\text { Trop } \\
\text { Med } \\
\text { Int } \\
\text { Health }\end{array}$ & Total \\
\hline Brazil & 15 & 8 & 2 & 0 & 5 & 7 & 3 & 122 & 12 & 0 & 2 & 176 \\
\hline United State & 9 & 96 & 8 & 1 & 1 & 9 & 2 & 4 & 6 & 2 & 15 & 153 \\
\hline India & 7 & 11 & 16 & 4 & 17 & 13 & 15 & 3 & 7 & 34 & 9 & 136 \\
\hline England & 8 & 14 & 10 & 7 & 4 & 3 & 4 & 2 & 14 & 9 & 21 & 96 \\
\hline Nigeria & 0 & 1 & 2 & 8 & 0 & 3 & 1 & 0 & 1 & 29 & 3 & 48 \\
\hline Turkey & 2 & 2 & 2 & 14 & 1 & 18 & 0 & 3 & 0 & 2 & 0 & 44 \\
\hline France & 4 & 8 & 5 & 0 & 0 & 2 & 1 & 1 & 3 & 2 & 9 & 35 \\
\hline Thailand & 6 & 11 & 3 & 3 & 0 & 0 & 0 & 0 & 7 & 1 & 4 & 35 \\
\hline Germany & 8 & 4 & 2 & 0 & 0 & 2 & 1 & 0 & 3 & 0 & 13 & 33 \\
\hline Argentina & 4 & 13 & 3 & 0 & 0 & 0 & 0 & 8 & 0 & 0 & 1 & 29 \\
\hline Netherlands & 3 & 8 & 3 & 1 & 0 & 0 & 6 & 0 & 0 & 1 & 7 & 29 \\
\hline Japan & 5 & 10 & 0 & 0 & 4 & 1 & 2 & 0 & 0 & 4 & 2 & 28 \\
\hline South Africa & 3 & 1 & 0 & 0 & 0 & 3 & 0 & 0 & 4 & 3 & 11 & 25 \\
\hline Belgium & 1 & 5 & 0 & 0 & 0 & 0 & 0 & 0 & 0 & 0 & 18 & 24 \\
\hline Kenya Netherlands & 9 & 4 & 0 & 0 & 0 & 0 & 0 & 0 & 1 & 3 & 7 & 24 \\
\hline
\end{tabular}


TABLE VI

Types of references of the eleven journals in tropical medicine in 2004

\begin{tabular}{lrrr}
\hline & \multicolumn{2}{c}{ Type of reference } & Total number \\
Journal & Periodical & Book and other sources & 3818 \\
\cline { 2 - 3 } Acta Trop & $3392(88.84)$ & $426(11.16)$ & 9476 \\
Am J Trop Med Hyg & $8518(89.89)$ & $228(9.92)$ & 2298 \\
Ann Trop Med Parasit & $2070(90.08)$ & $129(11.45)$ & 1127 \\
Ann Trop Paediatr & $998(88.55)$ & $82(11.26)$ & 728 \\
Int J Leprosy & $646(88.74)$ & $214(14.62)$ & 1464 \\
J Trop Pediatrics & $1250(85.38)$ & $147(16.00)$ & 919 \\
Leprosy Rev & $772(84.00)$ & $504(10.75)$ & 4688 \\
Mem Inst Oswaldo Cruz & $4184(89.25)$ & $310(12.25)$ & 2530 \\
Trans R Soc Trop Med Hyg & $2220(87.75)$ & $171(12.88)$ & 1328 \\
Trop Doct & $1157(87.12)$ & $889(17.29)$ & 5141 \\
Trop Med Int Health & $4252(82.71)$ & & \\
\hline
\end{tabular}

Numbers in the brackets indicate the proportion of different types of references in each journal.

TABLE VII

Publication year of citation of the eleven journals in tropical medicine in 2004

\begin{tabular}{|c|c|c|c|c|c|c|c|c|c|c|c|c|c|}
\hline \multirow[b]{2}{*}{ Journal } & \multicolumn{12}{|c|}{ Number of citation in different year } & \multirow{2}{*}{$\begin{array}{c}\text { Price } \\
\text { index } \\
(\%)\end{array}$} \\
\hline & 2004 & 2003 & 2002 & 2001 & 2000 & 1999 & 1998 & 1997 & 1996 & 1995 & The rest & Total & \\
\hline Acta Trop & 40 & 244 & 327 & 334 & 297 & 270 & 261 & 229 & 161 & 181 & 1474 & 3818 & 32.53 \\
\hline Am J Trop Med Hyg & 164 & 629 & 906 & 881 & 714 & 680 & 542 & 556 & 447 & 372 & 3585 & 9476 & 34.76 \\
\hline Ann Trop Med Parasit & 29 & 120 & 187 & 158 & 155 & 151 & 135 & 114 & 120 & 97 & 1032 & 2298 & 28.24 \\
\hline Ann Trop Paediatr & 13 & 43 & 88 & 85 & 87 & 79 & 72 & 65 & 55 & 65 & 475 & 1127 & 28.04 \\
\hline Int J Leprosy & 11 & 35 & 50 & 43 & 49 & 34 & 49 & 29 & 30 & 27 & 371 & 728 & 25.82 \\
\hline J Trop Pediatrics & 10 & 41 & 88 & 94 & 117 & 119 & 104 & 86 & 67 & 64 & 674 & 1464 & 23.91 \\
\hline Leprosy Rev & 16 & 37 & 57 & 46 & 63 & 62 & 68 & 40 & 39 & 31 & 460 & 919 & 23.83 \\
\hline Mem Inst Oswaldo Cruz & 56 & 246 & 298 & 360 & 311 & 303 & 263 & 282 & 200 & 210 & 2159 & 4688 & 27.11 \\
\hline Trans $R$ Soc Trop Med Hyg & 16 & 104 & 230 & 181 & 182 & 208 & 168 & 158 & 143 & 114 & 1026 & 2530 & 28.18 \\
\hline Trop Doct & 13 & 41 & 68 & 86 & 96 & 87 & 102 & 89 & 79 & 68 & 599 & 1328 & 22.89 \\
\hline Trop Med Int Health & 81 & 376 & 559 & 527 & 441 & 363 & 380 & 312 & 252 & 176 & 1674 & 5141 & 38.59 \\
\hline
\end{tabular}

TABLE VIII

Self-citing and cross-citing of the eleven journals in tropical medicine in 2004

\begin{tabular}{|c|c|c|c|c|c|c|c|c|c|c|c|c|c|}
\hline \multirow[b]{2}{*}{$\begin{array}{l}\text { Citing } \\
\text { journal }\end{array}$} & \multicolumn{9}{|c|}{ Cited journal } & & \multirow[b]{2}{*}{ Total } & \multirow[b]{2}{*}{$\begin{array}{l}\text { Self- } \\
\text { citing }\end{array}$} \\
\hline & $\begin{array}{l}\text { Acta } \\
\text { Trop }\end{array}$ & $\begin{array}{l}\text { Am J } \\
\text { Trop } \\
\text { Med } \\
\text { Hyg }\end{array}$ & $\begin{array}{c}\text { Ann } \\
\text { Trop } \\
\text { Med } \\
\text { Parasit }\end{array}$ & $\begin{array}{c}\text { Ann } \\
\text { Trop } \\
\text { Paediatr }\end{array}$ & $\begin{array}{l}\text { Int J } \\
\text { Lepr }\end{array}$ & $\begin{array}{c}J \\
\text { Trop } \\
\text { Pediat }\end{array}$ & $\begin{array}{c}\text { Leprosy } \\
\text { Rev }\end{array}$ & $\begin{array}{c}\text { Mem } \\
\text { Inst } \\
\text { Oswaldo } \\
\text { Cruz }\end{array}$ & $\begin{array}{c}\text { Trans } \\
R \text { Soc } \\
\text { Trop } \\
\text { Med Hyg }\end{array}$ & & $\begin{array}{c}\text { Trop } \\
\text { Med } \\
\text { Int } \\
\text { Health }\end{array}$ & & \\
\hline Acta Trop & 118 & 123 & 44 & 2 & 0 & 0 & 0 & 50 & 26 & 1 & 54 & 3818 & 3.09 \\
\hline Am J Trop Med Hyg & 202 & 909 & 133 & 7 & 3 & 9 & 5 & 127 & 159 & 12 & 286 & 9476 & 9.59 \\
\hline Ann Trop Med Parasit & 68 & 182 & 117 & 9 & 0 & 0 & 1 & 19 & 59 & 2 & 146 & 2298 & 5.09 \\
\hline Ann Trop Paediatr & 2 & 13 & 3 & 31 & 0 & 18 & 0 & 0 & 5 & 5 & 11 & 1127 & 2.75 \\
\hline Int J Leprosy & 0 & 15 & 0 & 0 & 139 & 4 & 133 & 4 & 9 & 0 & 0 & 728 & 19.09 \\
\hline J Trop Pediatrics & 0 & 14 & 1 & 14 & 0 & 33 & 1 & 2 & 6 & 6 & 10 & 1464 & 2.25 \\
\hline Leprosy Rev & 0 & 21 & 0 & 0 & 63 & 5 & 141 & 2 & 7 & 0 & 2 & 9191 & 15.34 \\
\hline Mem Inst Oswaldo Cruz. & 45 & 0 & 0 & 0 & 0 & 1 & 0 & 352 & 37 & 0 & 0 & 4688 & 7.51 \\
\hline Trans $R$ Soc Trop Med Hyg & 181 & 545 & 154 & 5 & 3 & 8 & 3 & 79 & 222 & 23 & 300 & 2530 & 8.77 \\
\hline Trop Doct & 1 & 7 & 2 & 2 & 0 & 0 & 1 & 1 & 3 & 28 & 15 & 1328 & 2.11 \\
\hline Trop Med Int Health & 62 & 209 & 52 & 4 & 0 & 10 & 1 & 18 & 55 & 12 & 264 & 5141 & 5.14 \\
\hline
\end{tabular}


TABLE XI

Journals most cited by the eleven journals in tropical medicine in 2004

\begin{tabular}{|c|c|c|c|c|}
\hline Ranking & Journal & Cited number & Cited rate $(\%)$ & 2004 Impact Factor \\
\hline 1 & Am J Trop Med Hyg & 1853 & 6.29 & 2.013 \\
\hline 2 & Trans $R$ Soc Trop Med Hyg & 1523 & 5.17 & 1.746 \\
\hline 3 & Lancet & 960 & 3.26 & 22.713 \\
\hline 4 & Trop Med Int Health & 687 & 2.33 & 1.969 \\
\hline 5 & Ann Trop Med Parasit & 603 & 2.05 & 1.162 \\
\hline 6 & J Infect Dis & 609 & 2.07 & 4.943 \\
\hline 7 & $B$ World Health Organ & 544 & 1.85 & 2.870 \\
\hline 8 & J Clin Microbiol & 493 & 1.67 & 3.439 \\
\hline 9 & Mem Inst Oswaldo Cruz. & 435 & 1.48 & 0.740 \\
\hline 10 & Acta Trop & 418 & 1.42 & 1.952 \\
\hline 11 & Parasitology & 316 & 1.07 & 1.685 \\
\hline 12 & Infect Immun & 306 & 1.04 & 4.033 \\
\hline 13 & Int J Leprosy & 304 & 1.03 & 0.426 \\
\hline 14 & Clin Infect Dis & 280 & 0.95 & 5.594 \\
\hline 15 & $J$ Med Entomol & 278 & 0.94 & 1.609 \\
\hline 16 & New Engl J Med & 266 & 0.90 & 38.570 \\
\hline 17 & Parasitol Today & 243 & 0.82 & $* * . * * *$ \\
\hline 18 & Leprosy Rev & 241 & 0.82 & 0.810 \\
\hline 19 & J Immunol & 233 & 0.79 & 6.486 \\
\hline 20 & Science & 222 & 0.75 & 31.853 \\
\hline
\end{tabular}

Among the 33,517 references, 29,459 were from 3575 periodicals. The first 20 periodicals that are most frequently cited by the eleven journals were listed in Table IX. These journals took the small proportion of all cited journals but provided the nearly half of all references $(10,814$ of total 29,459).

\section{DISCUSSION}

The number and type of papers published in the analyzed journals - The number of papers published by a journal reflects the amount of information contained. The average articles per issue and the average pages per papers are used to evaluate the document-loading capacity of a journal. The average number of papers per issue of these journals was 16.91. Tropical Doctor had the highest average number of papers per issue in 2004, whereas Transactions of the Royal Society of Tropical Medicine and Hygiene had the lowest (35.00 vs 9.33). The average number of pages per paper in the eleven journals ranged from 2.43 to 8.15, and Acta Tropica ranked first. The most common types of papers were articles, followed by letters.

Average number of authors per paper and number of paper coauthored - The number of authors is a criterion for evaluating the academic productivity of a journal. The average number of authors per paper in the journals was not markedly different, ranging from 2.93 to 6.37 . The proportion of coauthoring in the journals was from 60 to $97.03 \%$, which suggests that the scientific research increasingly requires collaboration within a team. Among the journals, Annals of Tropical Medicine and Parasitology had the highest degree of coauthoring while Leprosy Review lowest.

Country or region of the first author - The authors from Asia ranked highest in geographic distribution, with $23.34 \%$ of the total authors and publishing 324 articles. The authors from Europe (22.48\%) published 312 articles, South America $18.80 \%$, Africa, $17.36 \%$, and North America, 17.44\%. Memorias do Instituto Oswaldo Cruz, had strong geographical features, and the authors from its' own country accounted for $69.32 \%$ of the total authors.

The countries that have the largest number of authors in these eleven journals are, in descending order, Brazil, US, India, and England, indicating that they are ahead in tropical medicine research. The reasons Brazil and the US top the list, as shown in Table V, may be that there is a journal published by Brazil in eleven journals, and it published most articles written by Brazilians. Brazil and the US provide more funds and offer more opportunity for the research of tropical medicine, allowing researchers from Brazil and the US to do more studies on tropical medicine.

Average number and type distribution of references Reference is an important indicator that shows the extent of academic exchange and the ability to absorb external information of a journal and a discipline. The number of references, to some extent, reflects the quality and academic level of a paper. Among the eleven journals, American Journal of Tropical Medicine and Hygiene had the largest average number of references per article (31.59), while Tropical Doctor and Leprosy Review had much lower number of references. Periodicals are the main type of reference in the eleven journals, showing that the periodical is the most common type of resources used by researchers in tropical medicine.

Price index - A higher Price Index usually reflects more updated content in the publication. Higher Price Index also indicates that the researcher is in front of his re- 
search field. Usually Price Index of a newly forming discipline is higher than that of a long-standing discipline, and the average Price Index for all disciplines is about 50\% (Gao Jianqun et al. 2004). Price Indexes of the eleven journals varied from 22.89 to $38.59 \%$, with Tropical Medicine \& International Health being the highest and Tropical Doctor the lowest. The data shows that citing rate of recent references by the eleven journals and thus the ability of these journals to absorb and utilize new information is low. In general, the development of tropical medicine is slow.

Reference deviation - The fact that one journal is cited frequently by other journals shows that it is influential and plays important roles in its specialty. The 20 most cited journals are important information sources of tropical medicine for researchers. However, only eight of them are specialized tropical medicine journals, while others are from comprehensive science, general medicine, parasitology and immunology publications. That means the information from these fields are also crucial to the development of tropical medicine. Researchers of tropical medicine should be aware of this fact and librarians should take it into consideration when collecting periodicals in tropical medicine.

Self-citing and cross-citing - Except for self-citing, the American Journal of Tropical Medicine and Hygiene, Tropical Medicine \& International Health and Transac- tions of the Royal Society of Tropical Medicine and Hygiene were cited by other tropical journals. They were also on top of the most cited journal list. These results of self-citing analysis and crossing-citing analysis show that they are the most important sources for tropical medicine researchers.

\section{REFERENCES}

Fava GA, Ottolini F, Sonino N 2001. Which are the leading countries in clinical medicine research? A citation analysis (1981-1998). Psychother Psychosom 70: 283-287.

Gao Jianqun, Zhang Rongan, Chen Jiping, Shi Ye 2004. Periodical citation analysis and its information value. Library and Information Service 48: 58-61.

Garfield E 1972. Citation analysis as a tool in journal evaluation. Science 178: 471-479.

Garfield E 2000. Use of journal citation reports and journal performance indicators in measuring short and long term journal impact. Croat Med J 41: 368-374.

Rousseau R 1987. The Gozinto theorem: using citations to determine influences on a scientific publication. Scientometrics 11: 213-225.

Roy D, Hughes JP, Jones AS, Fenton JE 2002. Citation analysis of otorhinolaryngology journals. J Laryngol 116: 363366.

Schoonbaert D 2004. Citation patterns in tropical medicine journals. Trop Med Int Health 9: 1142-1150. 